\title{
Use of Agriculture Byproduct and Swamp Grass as Matterial for Ammoniation of Total Mixed Fiber in Ration on Ballinese Cattle Performance
}

\author{
Pemanfaatan Hasil Samping Pertanian dan Rumput Rawa sebagai Bahan \\ Amoniasi Total Mixed Fiber (TMF) dalam Ransum Terhadap \\ Performa Sapi Bali
}

\author{
A. Imsya*, Muhakka, \& F. Yossi \\ Department of Animal Science, Faculty of Agriculture, University of Sriwijaya \\ Palembang prabumulih street KM 32 Ogan Ilir District \\ *Email korespondensi: aimsya@yahoo.com
}

- Diterima: 15 April 2021 • Direvisi: 18 Mei 2021 • Disetujui: 18 Mei 2021

\begin{abstract}
This study was design to evaluated about the using of total mixed fiber ammoniation (TMFA) in ration on Ballinese beef performance. This study used an experimental method with Completely Randomized Design (CRD) consisting of 4 types of treatmentt ration based on TMFA usage level and 3 replications. The treatmentts were $\mathrm{R} 1=60 \%$ native grass (Control), R2 $=20 \%$ TMFA $+40 \%$ native grass, R3 $=40 \%$ TMFA $+20 \%$ native grass, $\mathrm{R} 4=60 \%$ TMFA. The ration is added with a $40 \%$ concentrate to obtain $100 \%$ ration. The comparison between forage and concentrate is 60:40. Parameters measured in vivo are performance (ration intake, dry matter intake, crude protein intake, daily body weight gain and ration efficiency). The results showed that treatmentt significantly influenced $(\mathrm{P}<0.05)$ on ration intake, dry matter intake, daily body weight gain and ration efficiency, but the treatmentt unsignificantly influenced $(\mathrm{P}>0.05)$ on crude protein intake. It can be concluded that the use of $60 \% \mathrm{TMF}$ ammoniation in the ration shows the best result, that is ration intake $6.89 \mathrm{~kg} / \mathrm{head} / \mathrm{day}$, dry matter intake $6.25 \mathrm{~kg} /$ head / day, daily weight gain $0.47 \mathrm{~kg} /$ head / day and efficiency of ration $7.42 \%$.
\end{abstract}

Key words: Beef production, ammoniation, total mixed fiber, technology, swamp grass, byproduct.

ABSTRAK. Penelitian ini mengevaluasi pemanfaatan amoniasi Total Mixed Fiber (TMFA) dalam ransum terhadap performa sapi Bali. Penelitian menggunakan Rancangan Acak Lengkap (RAL) dengan 4 perlakuan dan 3 ulangan. Perlakuan terdiri dari R1=60\% rumput Raja (control), R2 = 20\% TMFA $+40 \%$ rumput Raja, R3 = 40\% TMFA $+20 \%$ Rumput Raja, R4 $=60 \%$ TMFA. Ransum ditambah 40\% konsentrat untuk memperoleh 100\% ransum. Perbandingan hijauan dan konsentrat adalah 60:40. Parameter yang diukur adalah konsumsi ransum, konsumsi bahan kering, konsumsi protein kasar, pertambahan bobot badan dan efisiensi ransum. Hasil penelitian menunjukkan bahwa perlakuan memberikan pengaruh yang nyata $(P<0.05)$ terhadap konsumsi ransum, konsumsi bahan kering, pertambahan bobot badan dan efisiensi ransum, namun perlakuan tidak memberi pengaruh yang nyata (P>0.05) terhadap konsumsi protein. Kesimpulan dari penelitian adalah pemakaian amoniasi TMF $60 \%$ dalam ransum memberikan hasil terbaik dengan konsumsi ransum $6.89 \mathrm{~kg} / \mathrm{ekor} / \mathrm{hari}$, konsumsi bahan kering 6.25/kg/ekor/hari, pertambahan berat badan $0.47 \mathrm{~kg} / \mathrm{ekor} / \mathrm{hari}$ dan efisiensi ransum $7.42 \%$.

Kata kunci: Performa ternak, amoniasi, total mixed fiber, teknologi, rumput rawa, limbah pertanian.

\section{INTRODUCTION}

Fiber in ruminants feed plays an important role as the largest source of energy both for the growth of livestock and rumen microbes. Feed with fiber sources in ruminant rations is not only a source of energy but also a source to produce methane gas. In ruminants, such as cattle, buffalo, sheep and goats, feed with fiber sources will be fermented by rumen microbes to produce volatile fatty acids, carbon dioxide $\left(\mathrm{CO}_{2}\right)$, hydrogen $\left(\mathrm{H}_{2}\right)$ and microbial mass (Vlaming 2008).

Source fiber for ruminant could be from forage, agriculture waste and swamp grass. agriculture waste and swamp grass as feed matter for ruminant animal is used for replace forage or inconvensional feed. Combination of several agriculture waste and swamp grass with fiber and nutrient value different is called Total 
Mixed Fiber (TMF). Composition TMF from agriculture byproduct such as corn cobs, corn brands, rice straw and pineapple plantation waste significantly increased milk production but not significantly influence composition of milk on dairy cattle (Maneerat et al., 2013). Based on previous research, the use of TMF from agricultural waste in the form of oil palm frond, rice straw and swamp grass (kumpai tembaga) with composition of $20 \%$ oil palm fronds , $20 \%$ rice straw, and $20 \%$ swamp grass give the best results but the level of digestibility of dry matter and organic matter on this composition of TMF is still low, that is respectively $36.32 \%$ and $35.96 \%$, while the concentration of methane gas produced is at the lowest level of $6.91 \mathrm{mM}$ (Imsya et al., 2016) . Therefore, it is necessary to apply feed technology to improve nutrient digestibility of TMF such as ammoniation technology. Fiber sources with low of nutrient value and digestibility could be improve by treatment with chemical, physical and nitrogen sources (Nguyen et al., 2012). The ammoniation treatment reduces particle size and significantly increases the structure of inside and outside cell wall fragility so that decreaces acetyl group of the cell wall polysaccharides and then improve microorganism rumen for accessibility to the cell wall (Adejoro and Hassen, 2017), but Fang et al. (2012) reported that ammoniated straw was not significantly with untreatmentt ammonia for fragly of cell wall sothat gave the same for nutrient digestibility. Level of urea for amoniation as studied by Khejomsat and Wanapat (2010) who reported level of 3\% urea for rice straw result stability of nutrient value, $\mathrm{N}-\mathrm{NH}_{3}$, total VFA and propionate concentration by in vitro.
Several research about ration with ammoniated show that ration with urea treatmentt rice straw significantly increases dry matter intake, nutrient digestibility and concentration of propionic acid, total VFA and $\mathrm{NH}_{3}-\mathrm{N}$ on dairy Steer (Gunun et al., 2013). Hossain et al. (2010) reported that ration with rice straw and barley straw ammoniated result improving of $\mathrm{OM}, \mathrm{CP}, \mathrm{NDF}$ and $\mathrm{ADF}$ intake. So far, research on the use of TMF ammoniation in rations on Balinnes cattle has not been done and how the effect on Ballinese cattle performance is not known.

\section{MATERIALS AND METHODS}

\section{Ballinese Cattle and Diet}

This research was conducted at Animal Science Farm and Nutrition and Animal Feeding Laboratory, Agriculture Faculty, Sriwijaya University Indonesia. During 180 days from 8 April until 15 October 2019. Eexperimental method on 12 Ballinese cattle with body weight about $\pm 150 \mathrm{~kg}$. The design used was a Completely Random Design (CRD), with 4 types of treatmentt rations based on the level of use of TMF ammoniation. The treatmentts include R1 = $60 \%$ native grass, $\mathrm{R} 2=20 \% \mathrm{TMF}$ ammoniation + $40 \%$ native grass, $\mathrm{R} 3=40 \% \mathrm{TMF}$ ammoniation + $20 \%$ native grass, $\mathrm{R} 4=60 \% \mathrm{TMF}$ ammoniation. The ration is added with a $40 \%$ concentrate to obtain $100 \%$ ration. The comparison between forage and concentrate is 60:40. Parameters measured in vivo are performance including dry matter intake, daily body weight gain and ration efficiency.

Table 1. Nutrient contents of Feeds used in Treatmentt Rations (\%)

\begin{tabular}{llrrr}
\hline No. & Feed & Crude Protein & Crude Fiber & \multicolumn{2}{c}{ TDN } \\
\hline 1. & Rice Bran & 11.20 & 18.50 & 65.00 \\
2. & Ground Corn & 10.82 & 2.61 & 83.00 \\
3. & Tofu Waste & 11.60 & 7.79 & 70.00 \\
5. & Urea & 261.00 & 0.00 & 0.00 \\
6. & TMF Ammoniation & 6.65 & 27,91 & 66.99 \\
\hline
\end{tabular}

Source: Results of Analysis at Laboratory of Animal Nutrition and Feed, Sriwijaya University (2019). 
Table 2. Feeds Used as Concentrate Ingredients and Their Nutrient Contents (\%)

\begin{tabular}{llrrrrr}
\hline No. & Feed & Use & & Crude Protein & \multicolumn{1}{c}{ Crude Fiber } & TDN \\
\hline 1. & Rice Bran & 24.75 & 2.77 & 4.57 & 16.08 \\
2. & Ground Corn & 39.00 & 4.21 & 1.01 & 32.37 \\
3. & Tofu Waste & 35.00 & 4.06 & 2.72 & 24.50 \\
4. & Urea & 1.25 & 3.26 & 0.00 & 0.00 \\
\hline & Total & 100.00 & 14.31 & 8.31 & 72.95 \\
\hline
\end{tabular}

Source: Calculated by using data listed in Table 1 with the use of feed in concentrate.

Table 3. Nutrient Composition of Ration During the Experiment

\begin{tabular}{lrrrr}
\hline & \multicolumn{4}{c}{ Treatmentts } \\
\cline { 2 - 5 } Nutrien & R0 & \multicolumn{1}{c}{ R1 } & R2 \\
\hline CP & 5.08 & 5,54 & 5,61 & 6.25 \\
CF & 28,61 & 27,97 & 27,33 & 26,7 \\
TDN & 59,04 & 62,47 & 63,04 & 58,02 \\
NDF & 59.95 & 51.94 & 44.55 & 55.13 \\
ADF & 53.55 & 35.36 & 30.40 & 53.24 \\
Hemicelulosa & 6.40 & 16.58 & 14.15 & 1.89 \\
Celulosa & 36.33 & 25.89 & 22.40 & 40.13 \\
Lignin & 17.22 & 9.47 & 8.00 & 13.11 \\
\hline
\end{tabular}

\section{In vivo period}

It begins with a preliminary period for 30 days that is by weighing the initial body weight of the Ballinese cattle and then calculating the feed intake, which is composed of TMFA and concentrate, and drinking water given ad libitum. During this period, a process of adaptation to the treatmentt ration was performed, in which the Ballinese cattle were fasted in the morning and fed with treatmentt rations during the day. The treatmentt period was carried out for 15 days/period, while the interval of the adaptation period with the next treatment period was 3 days.

\section{Parameter Determination}

\section{Determination of ration, dry matter and crude protein intake}

Ration, dry matter and crude protein intake is measured by calculating the difference between the amount of feed and the remaining feed, meanwhile weighing is done every day in the afternoon and morning before the next feed is given.

\section{Determination of body weight gain (BWG)}

BWG is measured using a weighing scale once every 15 days or 1 period of research. BWG is obtained by calculating the difference between the final weight and the initial weight.

\section{Feed Efficiency (FE)}

FE is calculated by comparing feed intake and daily body weight gain then multiplied by $100 \%$.

\section{RESULT AND DISCUSSION}

The results of the treatmentt of TMFA levels in rations on the performance of Balinese cattle include ration intake, intake of dry matter and crude protein, body weight gain, and ration efficiency are shown in Table 4. 
Table 4. The average of ration intake ( $\mathrm{kg} /$ head / day), body weight gain ( $\mathrm{kg} / \mathrm{head} /$ day), and ration efficiency (\%) of Ballinese cattle with different levels of TMFA utilization in rations

\begin{tabular}{|c|c|c|c|c|c|}
\hline Treatmentts & $\begin{array}{l}\text { Ration Intake } \\
\text { (kg/head/day) } \\
\underline{+S E}\end{array}$ & $\begin{array}{l}\text { Dry Matter } \\
\text { Intake }+S E\end{array}$ & $\begin{array}{l}\text { Crude Protein } \\
\text { Intake }+S E\end{array}$ & $\begin{array}{l}\text { Average of Daily } \\
\text { Weight Gain }+ \text { SE }\end{array}$ & $\begin{array}{l}\text { Average of } \\
\text { Ration Efficiency } \\
\pm \text { SE }(\%)\end{array}$ \\
\hline R0 & $13.67 a+0.81$ & $11,77 a \pm 0,62$ & $0,62 \pm 0,14$ & $0,65^{a} \pm 0.05$ & $5.75^{b} \pm 0.13$ \\
\hline R1 & $12,60^{a} \pm 0.5$ & $11,24^{a}+0.47$ & $0,57 \pm 0.17$ & $0,45^{b}+0.01$ & $4.18^{c} \underline{-0.32}$ \\
\hline $\mathrm{R} 2$ & $10,25^{b}+0.17$ & $9,20^{b} \pm 0.11$ & $0,64 \pm 0.15$ & $0,35^{c}+0.04$ & $3.93 c+0.38$ \\
\hline R3 & $6.89 x+1.14$ & $6,23 c+0.97$ & $0,65 \pm 0.15$ & $0,47 \mathfrak{b} \pm 0.002$ & $7.42^{a} \pm 0.61$ \\
\hline
\end{tabular}

Note: A different superscripts on the same coloumn shows a significantly difference $(\mathrm{P}<0.05)$. R1 $=60 \%$ Native grass, $\mathrm{R} 2=20 \% \mathrm{TMFA}+40 \%$ Native grass, $\mathrm{R} 3=40 \% \mathrm{TMFA}+20 \%$ Native grass, $\mathrm{R} 4=60 \% \mathrm{TMFA}$.

The intake of Ballinese cattle ration in this study ranged from $6.89-13.67 \mathrm{~kg} / \mathrm{head} /$ day, with the dry matter intake range was 6.23-11.77 $\mathrm{kg} / \mathrm{head} /$ day and the intake of crude protein was $0.57-0.65 \mathrm{~kg} / \mathrm{head} /$ day. Based on the result of variance, it was found that the treatment had significant effect $(\mathrm{P}<0.05)$ on the intake of ration and the intake of dry matter, but was not significantly $(\mathrm{P}>0.05)$ on the intake of crude protein. Based on further tests for the parameters of feed intake and dry matter intake, it was found that the intake of ration and the intake of dry matter in the treatmentt of R0 and R1 was significantly $(\mathrm{P}<0.05)$ higher than the treatmentt of R2 and R3, while the intake of ration and dry matter on treatmentt $R 2$ is significantly higher $(P$ $<0.05)$ compared to R3. This indicates a decrease in ration intake and intake of dry matter in line with the increased use of TMFA in the ration. The treatment had no significant effect on protein consumption due to an increase in the protein content of the ration with a decrease in ration consumption for each treatment.

Treatment R0 gives the same effect as R1 on ration consumption because the use of native grass is still more than the use of TMFA so that the palatability are not so different. The decrease of ration intake is caused by decreased palatability of rations due to the use of TMFA in the ration. Rations with TMFA contents produce more odors and different colors than control rations. Palatability is an important factor in determining the level of ration intake. The palatability of the ration is determined by the taste, smell, and color of forage feed (McDonald et al., 2012). Huyen et al. (2012) reported that feed intake was affected with physical properties and palatability of feed. The improve in palatability might be due to the blending and processing of less palatable fibrous sources (Jaglan and Kishore, 2005). All of which are strongly influenced by the physical and chemical properties of the ration and may change due to the physiological and psychological differences of the individual livestock (Sebastian et al., 2020). Differences in intake levels are also influenced by various factors such as psychological factors (livestock in a healthy or sick or pregnant state), physiological factors (body weight, species, age, stomach capacity, and rumen digestion rate), feed factor (feed type, feed size, feed quantity, feed mixture, and palatability), and environmental factors (temperature and humidity) (Nurdiati et al., 2012). This result is not consistent with some previous study, urea treatmentt on feed stuff on steer and dairy cow fed had a higher ration intake when compared with non urea treatment (Ganum et al., 2013).

According to Sebastian et al. (2020), the ability to consume daily feed for each cow in the form of dry matter is as much as 3\% of body weight gain. The mean intake of dry matter in cows observed during the study was 7.60-9.70 $\mathrm{kg} / \mathrm{head} /$ day, or $3 \%$ of the weight of beef cattle. Based on these data, it was confirmed that the intake of dry matter in cows during the study was almost sufficient according to the need for beef cattle with a body weight of about $200 \mathrm{~kg}$.

The results of statistical analysis showed that the treatmentt significantly $(\mathrm{P}<0.05)$ affected the daily bodyweight gain of Balinese cattle. The treatmentt of R0 gave a significantly higher effect $(\mathrm{P}<0.05)$ than the other three treatmentts, while treatmentt of $\mathrm{R} 1$ and $\mathrm{R} 4$ showed a significantly different effect $(\mathrm{P}>0.05)$, but significantly higher $(\mathrm{P}<0.05)$ than treatmentt $\mathrm{R} 2$. The results showed that the treatmentt gave a significant effect $(P<0.05)$ on the ration 
efficiency. Based on further tests, feed efficiency with treatment R0 was significantly higher ( $P$ $<0.05$ ) compared with treatmentt R1 and R2, but lower than treatmentt R3. The feed efficiency between treatmentt of R1 and R2 was not significant $(\mathrm{P}>0.05)$, but both treatmentts were significantly $(\mathrm{P}<0.05)$ lower than the $\mathrm{R} 3$ treatment in feed efficiency.

Based on the measurement, the average of daily weight gain is $0.35-0.65 \mathrm{~kg} /$ head / day. The decrease of daily weight gain in the utilization of TMF ammonia in the ration is in line with the decrease of ration intake and dry matter intake. Cattle that have a high intake of rations followed by a normal digestion of nutrients will produce high body weight gain (Hafid and Rugayah, 2010). The DWG value is higher compared to DWG in Bali cattle fed with local-sourced rations in the range of 0.3-0.5 $\mathrm{kg} / \mathrm{head} /$ day (Hafid and Rugayah 2010), whereas the average DWG in heifer grazing legume and given feed mixture of agricultural waste and bran is 0.65-0.95 kg (Capper, 2012; Hristov et al., 2013). According to Auferre (2013), beef cattle with nutrient intake is less than requirement can not show optimal productivity because to increase the weight of beef cattle body must be fulfilled some needs, such as dry matter content, crude protein, and the addition of energy source. Based on the research results, it can be observed that the majority of feed ingredients used by farmers are rice straw with low nutrient value which causes low nutrient intake in beef cattle.

The efficiency of feed utilization in this study ranged from $3.93 \%-7.42 \%$. The highest feed efficiency was found in the R3 treatmentt of $7.42 \%$. This is due to the intake of dry matter at the treatmentt of R3 is lower, but the DWG is quite high. This shows that the use of $60 \%$ ammonia TMF in the ration produces good nutrients for weight gain. The high level of efficiency in R3 is due to the high protein content of the ration and the low content of crude fiber which increases the digestibility of the ration and the absorption of nutrients. Higher feed efficiency values indicate that the rations consumed to produce weight gain are less. Feed efficiency is influenced by several factors, including the ability of livestock in digesting the feed ingredients, the adequacy of nutrients for basic life, growth and body function, and type of feed According to Siregar (2001), feed efficiency for beef cattle ranged from $7.52 \%$ to $11.29 \%$. Several factors affect the feed efficiency, such as age, feed quality, and body weight. The better the feed quality, the better the efficiency for energy formation and production (Pond et al., 2005).

\section{CONCLUSIONS}

Based on the results of the study, it can be conclude that the use of $60 \%$ ammonia TMF in the ration gives the best result on ration for Ballinese cattle, dry matter intake of 6.25 $\mathrm{kg} / \mathrm{head} /$ day, daily weight gain of 0.47 $\mathrm{kg} / \mathrm{head} /$ day, feed efficiency of $7.42 \%$.

\section{CONFLICT OF INTEREST}

We declare that in this research there is no conflict of interests.

\section{RERERENCES}

Abate, D., and S, Melaku. 2009. Effect of supplementing urea-treated barley straw with lucerne or vetch hays on feed intake, digestibility and growth of Arsi Bale sheep. Tropical Animal Health Production. 41:579586.

Adejoro, F. A., and A, Hassen. 2017. Effect of supplementing or treating Eragrostis curvula hay with urea or nitrate on its digestibility and in vitro fermentation. S. Afr. J. Anim. Sci. 47: 168-177.

Association of Official Agricultural Chemists. 1995. Official method of analysis. 16th ed. Animal Feeds: Association of Official Analytical Chemists, VA, USA.

Aufrère, J., Dudilieu, M., Andueza, D., Poncet, C., Baumont, R. 2013. Mixing sainfoin and lucerne to improve the feed value of legumes fed to sheep by the effect of condensed tannins. Animal. 7: 82-92.

Capper, J.L. 2012. Is the grass always greener? Comparing the environmental impact ofbconventional, natural and grass-fed beef production systems. Animals. 2: 127-143.

Fang, J., M. Matsuzaki, H. Suzuki, Y. Cai, K. I. Horiguchi and T. Takahashi. 2012. Effects of lactic acid bacteria and urea treatmentt on fermentation quality, digestibility and ruminal 
fermentation of roll bale rice straw silage in wethers. Grassland Sci. 58:73-78.

Gunun P, Wanapat M, Nantasook, A, N. 2013. Effect of physical form and urea treatmentt of rice straw on rumen fermentation, microbial protein synthetis and nutrient digestibility in dairy steer. Asian Australian Journal Animal Science. 26(12):1689-1697.

Hossain, M, M, Khan M, J, Akbar MA. 2010. Nutrient digestibility and growth of local bull calves as affected by feeding urea and urease enzyme sources treated rice straw. Bang J Anim Sci. 39: 97-105.

Hafid, H., and N, Rugayah. 2010. Pengukuran sapi Bali dan ransum baku local. Prosiding seminar nasional teknologi peternakan dan Veteriner. Bogor

Hristov, A.N., Ott, T., Tricarico, J., Rotz, A.,Waghorn, G., Adesogan, A., Dijkstra, J.,Montes, F.,Oh, J., Kebreab, E., Oosting, S.J., Gerber, P.J., Henderson, B., Makkar, H.P.S., Firkins, J.L. 2013. Special topics -mitigation ofmethane and nitrous oxide emissions fromanimal operations: III. A review of animal management miti.

Huyen N T, M Wanapat and C Navanukraw. 2012. Effect of mulberry leaf pellet (MUP) supplementation on rumen fermentation and nutrient digestibility in beef cattle fed on rice straw-based diets. Animal Feed Science Technology. 175:8-15.

Jaglan, B, S., and N, Kishore. 2005. Compaction behavior of urea treated crop residues in feed blocks. Indian Journal Animal Nutrition. 22:90-93.

Khejornsart P, Wanapat M. 2010. Effect of chemical treatment of rice straw on rumen fermentation characteristic, anaerobic fungal diversity in vitro. J Anim Vet Adv. 9: 3070-3076.

Imsya A., Muhakka, dan Yosi ,F. 2016. Use of swamp 430 grass and agricultural waste as materials for total mixed fiber (TMF) in rations and its effect on methane gas production and production efficiency of beef cattle, Pakistan Journal of Nutrition. 15(4):342-346.

Maneerat W, Prasanpanich S, Kongmun S, Sinsmut W and Tumwasorn S. 2013. Effect of Feeding Total Mixed Fiber on Feed Intake and Milk Production in Mid Lactating Dairy Cows. Kasetsart Journal (Natural Science). 47:571580.
McDonald, P R A Edwards, J F D Green Halgh and C A Organ. 2012. Animal Nutrition. 6 $6^{\text {th }}$ Ed. Scientific and Technikal Co. Pubhlished. In The United State With John and Sons. Inc.New York . $\mathrm{p}$ :78-80

Nguyen V, N, M, Wanapat, Khejornsart, and P Kongmun. 2012. Nutrient digestibility and ruminal fermentation characteristic in swamp buffaloes fed on chemically treated rice straw and urea. Tropical Animal Health Production. 44:629-636.

Nurdiati, K., EcHandayanta, Lutojo. 2012. Efficiency of beef cattle production in the dry season at the people's farms in the dry land farming area of Gunung Kidul Regency. Tropical Animal Husbandry. 1(1):52-58.

Pond, W, G., D, C, Church, K, R, Pond, and P, A, Schoknecht. 2005. Basic Animal Nutrition and Feeding. Fifth Ed. John Wiley and Sons, Inc. United States. 91-109.

Sebastian L, A, C., Karen A. Beauchemin D, Jennifer MacAdam B, Juan J. Villalba A. 2020. Grazing diverse combinations of tanniferous and nontanniferous legumes: Implications for beef cattle performance and environmental impact. Science of the total environmental. 746:140-788.

Siregar, S. 2001. Ruminant Animal Ration. Penebar Swadaya, Jakarta.

Steel R, G, D., and J, H, Torrie. 2002. Principles and Procedures of Statistics: A Biometrical Approach. Second Edition. McGraw-Hill Book Company, London. 633 p.

Vlaming J, B. 2008. Quantifying Variation in Estimated Methane Emission from Ruminants Using the SF6 Tracer Fechnique. A Thesis of Doctor of Phylosophy in Animal Science. Massey University, Palmerston North, New Zealand.

Wanapat, M. 2009. Rumen manipulation to increase the efficient use of local feed resources and productivity of ruminants in the tropics. AsianAustralian Journal Animal Science. 26:529-536. 